\title{
Challenges for the Dutch polder model: Performance, Populism and Political Economy
}

\author{
Alexandre Afonso*
}

\section{Introduction}

The totemic status of the Dutch polder model may have waned somewhat since the publication of Visser and Hemerijck's Dutch Miracle in 1997, but in comparative terms Dutch neo-corporatism - the system whereby trade unions and employers get to decisively shape social and economic policies - still displays a remarkable degree of stability compared with other European countries. Ireland, for instance, another country considered a neo-corporatist miracle in the 1990s and 2000s, has witnessed the virtual collapse of its social partnership model in the aftermath of the financial crisis (Culpepper \& Regan, 2014). While neo corporatism seemed to have undergone a revival in Southern Europe in the 1990s (Hancke \& Rhodes, 2005), the crisis and the perceived need to cut back spending have led to the marginalization of employers and trade unions there as well, with the possible exception of Portugal. Austrian corporatism, probably one of the most developed in the world, has seen its legitimacy undermined by populist challengers (the Freiheitliche Partei Österreichs (FPö), the Austrian counterpart of the Partij voor de Vrijheid (PVV)), and scandals involving banks controlled by the trade unions (Afonso, 2013). While Switzerland has also performed well in the aftermath of the crisis, the role of social partners there has also been challenged by party polarization and the strengthening of populist parties (Häusermann, Mach \& Papadopoulos, 2004; Afonso \& Papadopoulos, 2015).

In contrast, while the Dutch economy has also faced serious consequences as a result of the financial crisis, notably a high level of household debt, and its political system has faced a similar populist upsurge coming from Geert Wilders's PVV, the Dutch polder model seems to display a good level of resilience in the face of these challenges. Hence, the volume edited by Maarten Keune draws a nuanced picture of the polder model, looking at its economic performance and political legitimacy. Drawing on the contributions of the book, I will address a series of challenges facing the Dutch polder model, mainly from a comparative perspective, and seek to answer why it seems to have survived. I will first draw in assessments of the current state of the polder model based on the contributions of the book, then address the following challenges: political change and the challenge of populist parties and changes in the economic structure at the level of finance and labor markets.

* Dr. Alexandre Afonso is assistant professor aan de Universiteit van Leiden. 


\section{Performance}

As made clear in the chapter by Braun, as well as Keune's introductory chapter, the legitimacy and resilience of neo corporatism rested on its ability to deliver better economic performance (output legitimacy). This performance would outweigh its drawbacks in terms of input legitimacy, that is, its weak ability to represent the preferences of a majority of voters. In the words of Norwegian political scientist Stein Rokkan (1966), in neo corporatism, 'votes count, but resources decide'. The Dutch polder model matched this idea: social pacts negotiated between trade unions, employers and the government have shaped a number of important reforms in social protection, labor market regulation and wage setting while parliament often merely rubber-stamped agreements. From the point of view of input legitimacy, this is problematic given that only one in six Dutch workers is a member of a trade union.

But is this democratic deficit justified by superior economic performance? As shown by Visser in his contribution, the Dutch economy has been performing well over the last decades in terms of both employment and equality. While employment levels have been among the highest in Europe, especially among women and young people, the Dutch labor market has been astonishingly spared by the rise in (income) inequalities that has spanned all advanced economies since the 1980s. This pattern can be accounted for by the persisting high coverage of collective labor agreements in spite of the dwindling membership of trade unions (outlined in the contribution by Paul de Beer), and the expansion of employment underpinned by the creation of a large number of - mostly part-time - jobs. Hence, the Dutch model is a good example of the 'high employment road to low inequality' presented by Kenworthy (2009; Afonso \& Visser, 2014). Arguably, as Keune makes clear, the Dutch economy has been an outstanding jobs-creation machine, but not a work-creation machine if one considers the huge proportion of part-time jobs in the economy and the total number of working hours performed. Yet, work-sharing via the wide distribution of part-time work - as compared to the concentrated participation on (male) full-time workers that prevails in Southern Europe, for example - is arguably a good solution to achieve low inequality in a political context which doesn't allow for mass public sector expansion, as in Scandinavian countries. Hence, one possible reason for the survival and resilience of the polder model is that it has made it possible to deliver both economic performance and provided an effective shield against inequality.

The main output-related argument in favor of the polder model has been that a particular type of political process involving cooperation between unions and employers has been the cause of the good economic performance of the Dutch economy. The main transmission channel connecting them has been wage restraint: by containing wage increases, the polder model has allegedly made it possible to preserve the competitive position of the largely export-oriented Dutch economy, and deliver better employment outcomes. However, this causal relationship can be questioned in a number of respects. One of the most severe criticisms is the one expressed by Ewald Engelen. Rather than an export-driven success, Dutch economic performance has been the result of a hybrid system where 
the domestic consequences of wage restraint have been compensated by a form of 'private Keynesianism' propelled mostly by mortgage debt. Hence, high employment could have happened despite, rather than because of the polder model of wage compression. While wage restraint has dampened domestic demand, mortgage debt has been used to boost it, notably policies such as the relaxation of borrowing rules and the hypotheekrenteaftrek. Hence, the high level of household debt in the Netherlands - Dutch households were the most indebted in the euro area in 2015, with debt representing 283 per cent of household income - may actually be a flipside of the polder model. This high level of indebtedness is often presented as a major reason for the slow recovery of the Dutch economy after the crisis in comparison with, say, Belgium (Financial Times, 2016). After the fall of house prices, Dutch households have sought to balance their books and postponed consumption.

\section{Populism and Electoral Fragmentation}

The first challenge faced by the Dutch polder model is the increasing fragmentation of the Dutch party system, the weakening of the traditional advocates of corporatist compromises in the legislative arena, and the rise of a populist party claiming to represent the traditional base of trade unions. As emphasized by Keune in his contribution, strong corporatism needs a strong government. This has been especially important when it comes to the regulation of the labor markets via Collectieve Arbeids Overeenkomsten (CAOs) (explained in the contribution by Verhoeff). In the face of declining trade union membership, political intervention has been a pillar of corporatist compromises by systematically extending collective bargaining outcomes and making them compulsory. Traditionally, the parties that have defended corporatist compromises in the Dutch context have been the Partij van de Arbeid ( $\operatorname{PvdA}$ ) and to some extent the Christen-Democratisch Appèl (CDA). Now, these parties have faced a dramatic electoral decline over the last decades. In 1993, the CDA and the PvdA represented 66 per cent of parliamentary seats in the Tweede Kamer. After the 2012 elections, this share had fallen to 33 per cent, and projections for the 2017 elections at the time of writing gave 8 per cent and 10 per cent for the $\mathrm{PvdA}$ and the CDA respectively. Hence, the channels of transmission of the polder model into politics have become fairly thin.

The new parties that have emerged or been strengthened in recent years have adopted a generally more critical stance towards neo-corporatist institutions, and had less problems with sidelining trade unions and employers. The 'Lenteakkoord' concluded in 2012 between the Volkspartij voor Vrijheid en Democratie (VVD), CDA, Democraten '66 (D66), ChristenUnie (CU) and GroenLinks (GL) is an example. One reason is that the extreme proportionality of the Dutch electoral system has facilitated the autonomisation of new middle class constituencies and their move away from the core of social democracy to new parties (D66, GroenLinks; 50+ and others) with somewhat different socio-economic positions, and the weakening of their organic ties with trade unions. In other countries where 
the electoral system makes it more difficult for new parties to emerge, these constituencies are kept together, usually under the umbrella of a social-democratic party.

The counterpart of the shrinking of the pro-polder parties in parliament has been the rise of the PVV as a powerful opposition force with a resolute anti-polder position. In his Onafhangelijkeidverklaring from 2005, Wilders wrote that the polder model 'moet op de helling, zonder pardon, en dat betekent dus het einde van de praat- en overlegpaleizen als de SER en de Stichting van de Arbeid', as well as: 'het afschaffen van het algemeen verbindend verklaren van cao's' (PVV 2005).

As other populist parties in Europe, the PVV has been very critical of neo-corporatist institutions perceived to work like a political cartel from which it is mostly excluded. Dismantling it is a way to undermine the cozy relationship between mainstream parties and interest groups, and especially trade unions. Interestingly, trade unions typically represented the socio-economic clienteles that the PVV is now mostly claiming, namely older, low-and-middle skilled working class workers. Weakening their influence can also be part of a strategy to become the only voice of this constituency. In 2011, for instance, the PVV proposed to give voting rights to non-union members in the negotiations of collective labor agreements as a way to dilute the influence of labor organisations (BNR, 2011).

This being said, the increasing fragmentation of the party system may not necessarily mean the end of the polder model. Indeed, as examples in other countries show, the polarization of politics may actually constitute an opportunity for social partners because of their continuing ability to reach compromises when political parties can't (Afonso, 2013). Hence, in the perspective of a multi-party government in which agreements may be difficult to reach, readymade solutions by social partners may still be able to make their way into policy.

\section{Political Economy and Economic change}

The last important challenge for the polder model is the change in its politicaleconomic structure. This mainly relates to the evolution of the labor market and its attainment of a potential ceiling and the increasing financialisation of the Dutch economy, especially when it comes to the pension system (explained in the contribution by Van der Zwan).

The first challenge has to do with the ability of the polder model to deliver superior economic performance, especially when it comes to women. In many respects the 'jobs miracle' that took place in the Netherlands in the 1980s and 1990s was based on the creation of part-time jobs mainly taken up by women. This expansion was fairly spectacular, but it was mainly a catching-up phenomenon in comparative terms because female employment in the Netherlands started at very low levels. In fact, The Netherlands had the lowest level of female labor force participation in Europe 1971, nearly 20 per cent below the OECD average. The publication of the Dutch Miracle in 1997 corresponded to this level just about reaching the OECD average. Since then, the potential for increasing female labor force participation has shrunk, and the rate of increase between 1996-2015 and 
1985-1995 has halved. Now it is unclear which potential source of labor can be used to increase the labor force. If the output legitimacy of the polder model was based on mass job creation, it may now be running out of steam.

The second aspect relates to the increasing financialisation of the Dutch economy, the in-built volatility this introduces, and how it changes the preferences of the actors involved. First, the compromises that underpinned the polder model were premised on the ability of domestic actors to exert some control over economic parameters via economic policy choices. Second, it was based on a class compromise between actors with clear interests, namely employers wanting wage restraint and trade unions wanting jobs, better purchasing power and/or social protection. As outlined in Van der Zwan and Engelen's contributions, these assumptions have been severely challenged by the tremendous increase in the level of financialisation of the Dutch economy. In 1995, stocks traded represented 25 per cent of Dutch GDP. By 2000 they represented 150 per cent, increasing to 183 per cent in 2007 (and also volatility increased, notably after the Dot.com bubble and the global financial crisis). This factor has challenged some basic tenets of the polder model in two major ways. First, the heavy level of involvement of pension funds jointly managed by social partners in financial markets has blurred the interests of capital and labor. The future income of workers via pension benefits is tied to investment decisions which may go against the interests of other workers, for instance by favoring short-term profits over long-term investments. In a nutshell, workers have become capitalists by procuration. Secondly, and most importantly the high level of volatility and uncertainty brought in by financialisation has made corporatist compromises extremely vulnerable to events happening in financial markets, which are globalized. Hence, it has become more difficult for corporatist actors to make credible commitments - e.g. about pension benefits - since revenues are largely beyond their control, and are (therefore) volatile.

In sum, while the polder model has indeed displayed a fairly high degree of resilience, it hasn't been immune to broader political and economic developments which will possibly fundamentally transform it in the long term. While it is unlikely to disappear, it may however be deprived of much of its regulatory capacity in a context of financialisation. The economic 'Miracle' which attracted wide international attention is going to be difficult to sustain, let alone renew. Keune's edited volume convincingly recognizes its successes, but also convincingly highlights its many hidden vectors of instability.

\section{Literature}

Afonso, A. (2013). Social Concertation in Times of Austerity. Amsterdam: Amsterdam University Press.

Afonso, A., \& Papadopoulos, Y. (2015). How the Populist Radical Right Transformed Swiss Welfare Politics: From Compromises to Polarization. Swiss Political Science Review, 21 (4): 617-635.

Afonso, A., \& Visser, J. (2014). The Liberal Corporatist Road to High Employment and Low Inequality? The Dutch and Swiss Social Models in the Crisis. In: J.E. Dølvik \& A. Mar- 
tin, European Social Models from Crisis to Crisis: Employment and Inequality in the Era of Monetary Integration. Oxford: Oxford University Press.

BNR (2011). Jacht op vakbonden is geopend. www.bnr.nl/nieuws/10202966/jacht-opvakbonden-is-geopend?disableUserNav=true, geraadpleegd op 4 januari 2017.

Culpepper, P.D., \& Regan, A. (2014). Why Don't Governments Need Trade Unions Anymore? The Death of Social Pacts in Ireland and Italy.' Socio-Economic Review, 12 (4): 723-745.

Financial Times (2016). Why is the Netherlands doing so badly?https://ftalphaville.ft.com/ 2016/06/16/2166258/why-is-the-netherlands-doing-so-badly/, geraadpleegd op 4 januari 2017.

Hancke, B., \& Rhodes, M. (2005). EMU and Labor Market Institutions in Europe: The Rise and Fall of National Social Pacts. Work and Occupations, 32 (2): 196-228.

Häusermann, S, Mach, A., \& Papadopoulos, Y. (2004). From Corporatism to Partisan Politics: Social Policy Making under Strain in Switzerland. Swiss Political Science Review, 10 (2): 33-59.

Kenworthy, L. (2009). The High-Employment Route to Low Inequality. Challenge, 52 (5): 77-99.

Partij voor de Vrijheid (2005) Onafhankelijkheidsverklaring. www.pvv.nl/index.php/ component/content/article/30-publicaties/684-onafhankelijkheidsverklaring, geraadpleegd op 4 januari 2017.

Rokkan, S. (1966). Norway: Numerical Democracy and Corporate Pluralism. In: R.A. Dahl (red.), Political Oppositions in Western Democracies. Yale: Yale University Press.

Visser, J., \& Hemerijck, A. (1997). Een Nederlands Mirakel. Amsterdam: Amsterdam University Press. 